\title{
Requirements for Scaling International Social Enterprises
}

\author{
Marek Ćwiklicki
}

\begin{abstract}
A B S T R A C T
Objective: The article aims to identify the requirements for a social enterprise to scale internationally. The explicit research objective is to explain which requirements enable to scale social ventures internationally with success.

Research Design \& Methods: The study employs a multiple case study analysis based on systematic literature review used to identify papers examining international social enterprises. In total six cases were analysed using the criteria of organisational capabilities included in the SCALERS model.
\end{abstract}

Findings: The analysis showed that the most significant for scaling social enterprises internationally are: earnings generation and alliance building; next staffing, communicating, and replicating. Less significant are lobbying and stimulating market forces.

Implications \& Recommendations: The existence of a strong business model, neutral from market sources, well-resourced, recognised in the public sphere associated with scaling up.

Contribution \& Value Added: The article contributes by revealing that capabilities for ISEs scaling are varied in terms of their significance. The presented results go along with the observation that prior to scaling social impact the basic operational model must show its viability.

\begin{tabular}{ll}
\hline Article type: & research article \\
Keywords: & social entrepreneurship; internationalisation; scaling; SCALERS \\
JEL codes: & L31, F23
\end{tabular}

\section{Suggested citation:}

Ćwiklicki, M. (2019). Requirements for Scaling International Social Enterprises. Entrepreneurial Business and Economics Review, 7(1), 45-60. https://doi.org/10.15678/EBER.2019.070103 


\section{INTRODUCTION}

The article aims to identify the requirements for a social enterprise to scale internationally. As most of the scholarship concentrates on national social entrepreneurship good practices and national settings, the issue of internationally operating social enterprises seems to be not-well researched. The 'social' aspect in the context of international entrepreneurship is also not always distinguished in the research (cf. Jones, Coviello, \& Tang, 2011; Keupp \& Gassmann, 2009). This was the main reason why this topic was chosen for consideration.

The explicit research objective is to explain which requirements enable to scale social ventures internationally with success. For this purpose the SCALERS model was chosen as the analytic framework (Bloom \& Chatterji, 2009; Bloom \& Skloot, 2010; Bloom \& Smith, 2010a). In this exploratory research first the systematic literature review was employed in order to identify papers about international social enterprises (ISEs). In total six cases were recognised and coded according to the SCALERS criteria. These cases are: Benetech, Fairtrade International, KickStart International, Teach for All, Vestergaard Frandsen, and Viva Rio. The most significant factors were established after content analysis based on their joint description in secondary scholar papers.

The article is structured as follows. First, the theoretical background of international social entrepreneurship and the SCALERS model is presented. Next, the research method and materials are discussed. After that, the results are presented, covering each of the main capabilities derived from the SCALERS model: staffing, communicating, alliance-building, lobbying, earnings generation, replicating, and stimulating market forces. The limitations of the study and the direction of future research are discussed in the last section of the article.

\section{LITERATURE REVIEW}

\section{International Social Enterprises}

In spite of the growing body of literature about international entrepreneurship (cf. Jones et al., 2011; Keupp \& Gassmann, 2009), its social side is still unrecognised. One of the potential reasons lies in a different nature of social entrepreneurship. Desa notes that 'descriptions of social entrepreneurship differ widely across international contexts from the narrow to the all-encompassing' (Desa, 2012, p. 728). Matching two separate issues: international entrepreneurship (IE) and social entrepreneurship (SE) leads to intersection consisting of the social aspect of doing business taken from SE and the international one taken from IE. The results of this intersection are international social ventures providing blended value, i.e., 'blends of financial, social, and environmental values' and aiming at social change (Zahra, Newey, \& Li, 2014, p. 140). The seminal definition of IE was provided by Oviat and McDougall, who argued that IE is the discovery, enactment, evaluation, and exploitation of opportunities - across national borders - to create future goods and services' (Oviatt \& McDougall, 2005, p. 250). Another offered definition is based on the synthesis of previous scholarship and characterises ISE as: 
'the process of creatively discovering and exploiting social entrepreneurial opportunities overseas with the application of business expertise and market-based skills, with innovative social goods and services, either with or without profit orientation, but with the pivotal objective of creating societal value rather than shareholder wealth in the overseas territories where the enterprise functions.' (Tukamushaba, Orobia, \& George, 2011, p. 258).

Within this context three aspects influencing the cross-border business are worth mentioning: cross-border uncertainty, limited resources, and network dynamics (Sarasvathy, Kumar, York, \& Bhagavatula, 2014; Zemaitaitiene et al., 2016; Ratajczak-Mrozek). It establishes the initial set of problems which ISEs must face.

The distinction between for-profit and not-for profit ISE leads to the formulation of propositions based on the literature review (Yang \& Wu, 2015). For-profit ISEs choose a more safe scaling up mode, while they do not experiment with operational modes focus and the choice of products. Expansion to other countries is based on two grounds: the forprofit ISEs choose those countries where a similar environment exists (or customers can be met), while not-for profit ISEs try to answer similar problems as in the original setting.

The literature review on ISEs allows to confer that this kind of business venture is quite new in scholarship although in recent years it has started to gain interest. This attention was raised mainly due to the project aimed at investigating the cross-national setting, such as International Comparative Social Enterprise Models (ICSEM) (Abbou et al., 2017; Brouard \& Elson, 2014; Defourny \& Nyssens, 2017).

There is no official nor unofficial data about the number of operating ISEs. Based on the cases identified for the purpose of this study, discussed in the 'Methods and material' section, one can conclude that only a few ventures become successful in expanding business internationally. It urges to investigate the reasons for thriving beyond the original settings.

\section{The SCALERS Model}

In this article I discuss the scaling social impact issue which gains international interest (e.g., Bradach, 2010; Dees, Anderson, \& Wei-Skillern, 2004; Galera \& Borzaga, 2009; Walske \& Tyson, 2015; Weber, Kröger, \& Lambrich, 2012; Westley, Antadze, Riddell, Robinson, \& Geobey, 2014). But first the meaning of scaling (up) social entrepreneurship needs to be explained. Searching for the spread of the impact of social entrepreneurs leads to the distinction between dissemination, affiliation and branching (Dees et al., 2004). These ways of growth are quite well described in the literature though the framing parts of the most appropriate strategy are still questionable. Other similar expressions are: transferability, replicability and adaptability (Weber et al., 2012).

For the last twenty years a new research development has proved to be worth considering as potentially explaining success factors for scaling. Cases described in the literature give one piece of the puzzle: the number of staff. It spotlights the issue of resources and brings back to the discussion the resource-based theory as potentially capable to explain the scaling in social enterprises. Such a change happened in KaBOOM!, which is an example of the 'bricks-to-clicks' model (Bradach, 2010).

Scaling strategies were grasped by Weber, Kröger and Lambrich (2012). The Authors distinguished four modes: capacity-building, relationship defined by an ongoing 
agreement, diffusion of knowledge, and one adjacency move (Weber et al., 2012, p. 7). In the context of strategies, the individual decision making path appears to be a sign of successful operation of the basic operational model. It means that first this model must prove its viability.

Residing in the scope of interest in research, the next issue is driven by the assumption about the place where a potential for scaling up appears: inside or outside the organisation. Taken the most significant feature of social enterprises - social value provision, the shift from internal to external conditions appears, which finally brings a mixture of these two approaches.

Currently, the most popular model explaining the success of scaling social impact is the SCALERS model developed by Bloom and Chatterji and for the first time explained in 2009 (Bloom \& Chatterji, 2009; Bloom \& Smith, 2010a). It is still in the theory-testing phase and needs the confirmation of validity (Cannatelli, 2017).

The SCALERS model explains a success at scaling social impact as the results of development in seven independent capabilities from which the acronym SCALERS comes from, i.e.: Staffing, Communicating, Alliance building, Lobbying, Earnings generation, Replicating, and Stimulating market forces in certain situational contingencies (Bloom \& Skloot, 2010, p. 5; Petrů \& Havlíček, 2017). As the components of the SCALERS model are well described in the mentioned sources, only a short presentation will be given (Table 1). The SCALERS model stresses the importance of the external environment. It assumes that the organisation's success depends on its ecosystem. The situational contingencies are: labour needs, public support, potential allies, supportive public policy, start-up capital, and dispersion of beneficiaries. For the presented study it is important to note that success in scaling does not depend on excellence in all the factors indicated by the model (Bloom \& Smith, 2010a, p. 14). In fact, it could vary.

In this article the research subject is constituted by international social organisations which have already succeeded in scaling. In the SCALERS questionnaires the interviewers are asked to evaluate the organisation's own performance for the last three years and in comparison to other organisations (Bloom \& Smith, 2010a, p. 25). It is also a limitation of this study, as the established descriptions were adjusted to a particular category not related to other organisations. It can be justified by the international character of the research subjects as it would be not suitable to match up to any other ISE.

\section{MATERIAL AND METHODS}

The methodology used for this research belongs to comparative analysis based on the multiple case study approach. The analysed data come from a systematic literature review (SLR). The SLR was performed in order to identify papers examining international social enterprises. First, we applied queries using the phrases 'international social enterprise*' and 'international social entrepreneur*' in abstract and the full body of fulltext papers indexed in journal databases: EBSCO host, Scopus, Science Direct and Web of Science, which gave 1235 articles in total. The elimination of duplicates provided 248 papers. Next, we performed content analysis of each of the papers. This phase of research resulted in excluding 198 ones as not referring to the topic 'social enterprise/entrepreneurship' working internationally. Finally, 50 papers were qualified for thorough 
analysis. This phase resulted in the identification of six cases included in a detailed analysis using the SCALERS model. The reasons to reject papers from further examination were: not covering particular ISE enabling to evaluate it according to the accepted model, dealing with the internationalisation of SE but without references to a factual enterprise, describing only a hypothetical venture. Figure 1 depicts the procedure of selecting these cases and Table 2 contains a short description of them.

Table 1. The Description of the SCALERS Drivers

\begin{tabular}{|l|l|l|}
\hline \multicolumn{1}{|c|}{ Driver } & \multicolumn{1}{|c|}{$\begin{array}{c}\text { Depending situational } \\
\text { contingency }\end{array}$} & \multicolumn{1}{c|}{ Explanation } \\
\hline 1. Staffing & labour needs & $\begin{array}{l}\text { Hired staff (employees or volunteers) possessing } \\
\text { necessary skills for given job positions }\end{array}$ \\
\hline $\begin{array}{c}\text { 2. Communi- } \\
\text { cating }\end{array}$ & public support & $\begin{array}{l}\text { Successful persuading key stakeholders (donors, } \\
\text { own personnel, beneficiaries, consumers, general } \\
\text { public) to support the organisation in its change }\end{array}$ \\
\hline $\begin{array}{c}\text { 3. Alliance- } \\
\text { building }\end{array}$ & potential allies & $\begin{array}{l}\text { effectiveness in creating partnerships (coalitions, } \\
\text { joint ventures, etc.) }\end{array}$ \\
\hline $\begin{array}{l}\text { 4. Lobbying } \\
\text { 5. Earnings gen- } \\
\text { eration }\end{array}$ & $\begin{array}{l}\text { supportive } \\
\text { public policy }\end{array}$ & $\begin{array}{l}\text { gaining support from public administration institu- } \\
\text { tions in introducing change }\end{array}$ \\
\hline $\begin{array}{l}\text { 6. Replicating } \\
\text { 7. Stimulating } \\
\text { market forces }\end{array}$ & dispersion of beneficiaries & $\begin{array}{l}\text { having revenue exceeding the organisation's } \\
\text { expenses }\end{array}$ \\
\hline reproducing (copying) the programmes and initiatives \\
\hline
\end{tabular}

Source: own elaboration based on Bloom and Smith (2010a, pp. 12-17).

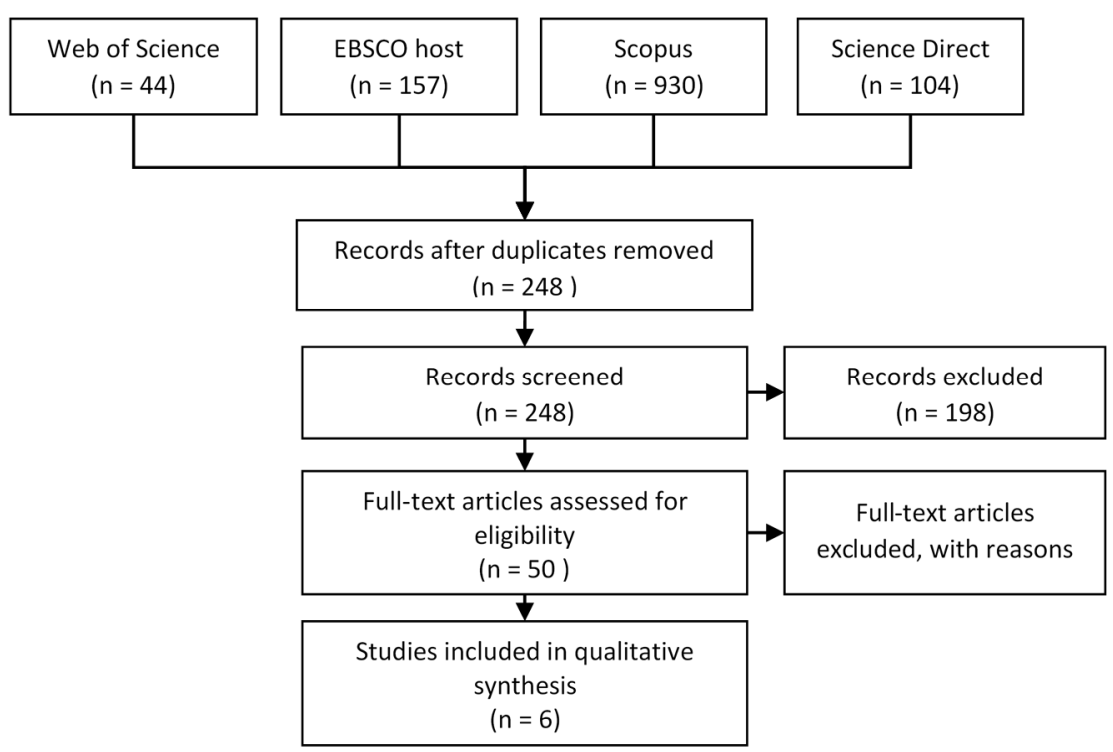

Figure 1. Stages in studies selection process

Source: own elaboration. 
The described cases come from recent papers (2012-2016). It supports the inference about the novelty of undertaking the problem although the ISEs have been operating since '90s. What these ISEs have in common is putting above social aim which is helping disadvantaged people. As the main purpose of the article is to concentrate on drivers, the detailed presentation of each company was omitted.

Table 2. Description of ISEs Included in the Research

\begin{tabular}{|c|c|c|c|c|c|c|}
\hline No. & Name of ISE & $\begin{array}{l}\text { Year of } \\
\text { est. }\end{array}$ & $\begin{array}{c}\text { Country of } \\
\text { origin }\end{array}$ & Business domain & $\begin{array}{c}\text { Area of op- } \\
\text { eration }\end{array}$ & Source \\
\hline 1. & Benetech & 1989 & USA & $\begin{array}{c}\begin{array}{c}\text { reading machine for } \\
\text { blind people }\end{array} \\
\end{array}$ & worldwide & (Desa, 2012) \\
\hline 2. & $\begin{array}{c}\text { Fairtrade } \\
\text { International }\end{array}$ & 2004 & Germany & $\begin{array}{l}\text { certification of fair } \\
\text { trade standards }\end{array}$ & worldwide & (Bennett, 2016) \\
\hline 3. & $\begin{array}{c}\text { KickStart } \\
\text { International }\end{array}$ & 1991 & USA & irrigation technology & Africa & $\begin{array}{c}\text { (Galvin \& } \\
\text { lannotti, 2015) }\end{array}$ \\
\hline 4. & Teach for All & 2007 & USA & education & worldwide & (Friedrich, 2014) \\
\hline 5. & $\begin{array}{l}\text { Vestergaard } \\
\text { Frandsen }\end{array}$ & 1957 & Suisse & $\begin{array}{l}\text { products for disad- } \\
\text { vantaged people }\end{array}$ & worldwide & $\begin{array}{c}\text { (Agrawal \& } \\
\text { Gugnani, 2014) }\end{array}$ \\
\hline 6. & Viva Rio & 1993 & Brasil & preventing violence & Brasil, Haiti & (Davis, 2016) \\
\hline
\end{tabular}

Source: own elaboration.

Based on the content analysis of the identified articles I coded particular phrases referring them to scaling social enterprises operating internationally. As codes I used names of organisational capabilities included in the SCALERS model. The analysis of each case showed the lack of information about each of the detailed criteria incorporated in the SCALERS model. Therefore, the following data treatment was used. For each of the measures the depiction from a particular case was inserted and marked with numbers (in brackets) from Table 2, which allows to trace which case they refer to. The further analysis is done separately towards each of the seven drivers.

\section{RESULTS}

The first capability in the SCALERS model refers to Staffing (Table 3). It starts with meeting labour needs with skilful people. In this area there is a lack of its full explanation. We can conclude that having own workers was just a core, a base for operations of the company, while an operating business requires trained workers and in two examined cases such inference can be drawn. The second criterion in Staffing refers to the availability of capable volunteers. In two identified cases the access was limited and ISE was based on full-time workers. The last condition pertains to possessing proper skills by managers to scale up. In this field we can observe having skilful managers in four cases. Their competences were secured thanks to the selection procedures. Overall, we can state about the general importance of staffing in ISEs with strong emphasis on formal HRM practices aimed at possessing competent workers.

The second part of the SCALERS is Communicating which can be expanded into external communication and public relations. The first point is about communicating to key stakeholders. Examples derived from three cases proved that branding was crucial. For 
that purpose ISEs used classical advertisement means, such as ads and campaigns with the goal to create the image of a professional, trustworthy organisation. The next section pertains to informing the individuals. Here the same tools as in the previous part were used, altogether with mass communication (declared in one case). The last communication is aimed at donors. In two cases we can see strong commitment to taking part in international venues showing transnational orientation of the social enterprises. Taken as a whole, this organisational capability presents as important for ISEs (Table 4).

Table 3. Staffing in International Social Enterprises

\begin{tabular}{|l|l|}
\hline \multicolumn{1}{|c|}{ Staffing } & \multicolumn{1}{c|}{ Examples } \\
\hline $\begin{array}{l}\text { Effective meeting of } \\
\text { labour needs with } \\
\text { people who have the } \\
\text { necessary skills. }\end{array}$ & $\begin{array}{l}\text { - not fully explained; only mentioned that there was not strong leadership (2) } \\
\text {-selected top university graduates without any previous pedagogical course } \\
\text { work (4) } \\
\text { - the organisation's staff working together with local trained staff (5) }\end{array}$ \\
\hline $\begin{array}{l}\text { An ample pool of ca- } \\
\text { pable volunteers avail- } \\
\text { able to help us meet } \\
\text { our labour needs. }\end{array}$ & $\begin{array}{l}\text { - mostly based on full-time workers (5) } \\
\text { Individuals at manage- }\end{array}$ \\
$\begin{array}{l}\text { ment positions who } \\
\text { have the skill to expand }\end{array}$ \\
$\begin{array}{l}\text { our organisation, pro- } \\
\text { gramme or principles. }\end{array}$ & $\begin{array}{l}\text { - operating own internal monitoring department in order to measure out- } \\
\text { comes on the lives of buyers (3) }\end{array}$ \\
\hline
\end{tabular}

Source: own elaboration.

Table 4. Communicating in International Social Enterprises

\begin{tabular}{|l|l|}
\hline \multicolumn{1}{|c|}{ Communicating } & \multicolumn{1}{c|}{ Examples } \\
\hline $\begin{array}{l}\text { Effective at communicating what } \\
\text { we do to key constituencies and } \\
\text { stakeholders. }\end{array}$ & $\begin{array}{l}\text { - operate in politically unstable countries (1) } \\
\text { - the ability to create and circulate a broadly defined group iden- } \\
\text { tity that appeals to multiple sets of potential supporters (6) } \\
\text { - brand itself as a development subcontractor specialising in } \\
\text { community-based interventions within precarious regions (6) } \\
\text { - communication campaigns to spread word of their struggles } \\
\text { to commiserating international audiences (6) }\end{array}$ \\
\hline $\begin{array}{l}\text { Successful at informing the indi- } \\
\text { viduals we seek to serve about the } \\
\text { value of our programme for them. }\end{array}$ & \\
\hline $\begin{array}{l}\text { Successful at informing donors billboards in target counties (2) } \\
\text { and funders about the value of } \\
\text { what we do. }\end{array}$ & $\begin{array}{l}\text { NGO that can work in multiple local contexts (6) } \\
\text { Naccessful at branding itself as a transnationally oriented }\end{array}$ \\
\hline
\end{tabular}

Source: own elaboration.

The third part of the SCALERS refers to partnership and is called 'alliance-building'. It starts with successful partnership building with win-win situations. It can be in a form of receiving 
donation of unnecessary equipment for the donors or supporting activities with the same social aim. Cooperation with others in new initiatives exists, but it was not often reported. Nevertheless, it appears to be more frequent in undertaking everyday actions (Table 5).

Table 5. Alliance Building in International Social Enterprises

\begin{tabular}{|c|c|}
\hline Alliance building & Examples \\
\hline $\begin{array}{l}\text { Partnerships built with } \\
\text { other organisations that } \\
\text { have been win-win situa- } \\
\text { tions for us and them. }\end{array}$ & $\begin{array}{l}\text { - received donations of the hardware which were not necessary for } \\
\text { the giving company (1) } \\
\text { - reaction to the call for projects which allowed the funding organisa- } \\
\text { tion to realise its goal, while ISE created an image of the leading } \\
\text { company in operations in the developing world (5) } \\
\text { - building strong connections with local NGOs instead of focusing on } \\
\text { single issues (6) } \\
\text { - co-sponsorship of other NGO projects in the country (6) } \\
\text { - financing other actions or projects which have a similar goal (6) } \\
\text { - networking with large NGOs has provided strong support (6) }\end{array}$ \\
\hline $\begin{array}{l}\text { Rarely trying to 'go it alone' } \\
\text { when pursuing new initia- } \\
\text { tives. }\end{array}$ & $\begin{array}{l}\text { - collaboration with other organisations working in the same areas } \\
\text { (human rights groups) (1) } \\
\text { - launching a project with other partners (5) }\end{array}$ \\
\hline $\begin{array}{l}\text { Accomplished more } \\
\text { through joint action with } \\
\text { other organisations than we } \\
\text { could have by flying solo. }\end{array}$ & $\begin{array}{l}\text { - working with other NGOs and foundations (1) } \\
\text { - cooperation with the country government workers (5) } \\
\text { - absorbing benefits from collaboration on the relationship between } \\
\text { building ties with local communities and assessing what type of in- } \\
\text { tervention the community requires (6) }\end{array}$ \\
\hline
\end{tabular}

Source: own elaboration.

Lobbying, the fourth section of the SCALERS model, was not expressed often in the examined texts. We can reason that lobbying is partially covered by public-partner partnerships. In the area of engaging government agencies in financial support was perceived as the recognition that official agencies were not successful to solve given problems as ISEs were. No observation was made about creating legal frameworks supporting ISEs activities in the identified cases. The last part of lobbying is about rising the cause to a higher place on public agenda. One observation proved that it had happened through escalating the problem to international audience who put pressure on the local government (Table 6).

Table 6. Lobbying in International Social Enterprises

\begin{tabular}{|l|l|}
\hline \multicolumn{1}{|c|}{ Lobbying } & \multicolumn{1}{c|}{ Examples } \\
\hline $\begin{array}{l}\text { Successful at getting government agen- } \\
\text { cies and officials to provide financial sup- } \\
\text { port for our efforts. }\end{array}$ & $\begin{array}{l}\text { Showing that an undertaken action brings financial } \\
\text { benefits for the government (5) } \\
\text { - Showing that the organisation can successfully act in } \\
\text { the areas where others institutions do not. Proving ac- } \\
\text { cess to these areas (6) }\end{array}$ \\
\hline $\begin{array}{l}\text { Successful at getting government agen- } \\
\text { cies and officials to create laws, rules, and } \\
\text { regulations that support our efforts. }\end{array}$ & \\
\hline $\begin{array}{l}\text { Able to raise our cause to a higher place } \\
\text { on the public agenda. }\end{array}$ & - Through convincing strong partners to pressure from \\
\hline
\end{tabular}


The fifth part of the SCALERS models is Earnings generation. Deducing from the number of phrases referring to this topic, we can state that it is an important issue to ISEs. The first section describes the stream of sales revenues. Due to financial situation of the customers whose buying potential is weak, the sale is subsidised by donors (private or government ones). In one case the customer's credit was introduced. The second segment of earnings generation reflects donors and funders who have been major sources of revenue. It is strongly true in the investigated companies. The next factor, ways to finance ISE activities, also found clear evidence as showed by the case of Viva Rio. It was claimed that the evolution from local to national to transnational NGO had been facilitated by sizable grants from large multilaterals, national governments aid programmes, international foundations, CSR actions, and sizable allocations from municipal and state governments (Davis, 2016). The ability to find different sources of finance seems to be the crucial ISE's capability (Table 7).

Table 7. Earnings Generation in International Social Enterprises

\begin{tabular}{|c|c|}
\hline Earnings generation & Examples \\
\hline $\begin{array}{l}\text { Generated a strong } \\
\text { stream of revenues } \\
\text { from products and } \\
\text { services that we sell } \\
\text { for a price. }\end{array}$ & $\begin{array}{l}\text { - customers credit (1) } \\
\text { - not so important comparing to legitimacy. (2) } \\
\text { - heavily subsidised through donor financing ( } 3 \text { ) } \\
\text { - each local 'Teach for ...' programme is funded by public-private partner- } \\
\text { ships. } \\
\text { - support through grants from the governments of countries where ISEs op- } \\
\text { erate (4) (5) }\end{array}$ \\
\hline $\begin{array}{l}\text { Cultivated donors } \\
\text { and funders who } \\
\text { have been major } \\
\text { sources of revenue } \\
\text { for us. }\end{array}$ & $\begin{array}{l}\text { - Business partners allowed delayed payments (1) } \\
\text { - Tentativeness to achieve financial independence from grants and donations (3) } \\
\text { - Grants funding from a couple of donors (3) } \\
\text { - Using reputation and companies' CSR budgets for sponsorship of many } \\
\text { such programmes (4) } \\
\text { - Using funding from the city government (6) }\end{array}$ \\
\hline $\begin{array}{l}\text { Found ways to fi- } \\
\text { nance our activities } \\
\text { that keep us sus- } \\
\text { tainable. }\end{array}$ & $\begin{array}{l}\text { - sold business (1) } \\
\text { - financing coming from grants, (3) } \\
\text { - venture philanthropy 'microlending' (4) } \\
\text { - evolution from local to national to transnational NGO has been facilitated } \\
\text { by finance from a difference source (6) }\end{array}$ \\
\hline
\end{tabular}

Source: own elaboration.

Second to last driver for scaling social enterprises is Replication. Products or services offered by the identified companies showed to work effectively in multiple locations or situations as the name of the first factor indicates. Their products proved to function in different countries or - after adaptation - in different situations. For example, reading systems working in English operate also in other languages (case \#1). A solution elaborated to prevent violation becomes the base for a manual, a guidebook (case \#6). These illustrations show operational modes focused on product/service transactions between countries. They assume the universal nature of the problem to fight with. Only the scale of the occurrence of the issue demonstrates the usefulness of the solutions. The next point in replication is its ease. This issue is complex as some products/services depend on the individual attitude of a customer who is willing to benefit from it. It is especially visible for 
mindset changes but thanks to elaborated procedures, programmes and guidebooks, replication understood as launching the product in a new environment is quite easy. The description of controlling and coordinating programmes in multiple locations is missing. In one case we can point out such a possibility (Table 8).

Table 8. Replicating in International Social Enterprises

\begin{tabular}{|l|l|}
\hline \multicolumn{1}{|c|}{ Replicating } & \multicolumn{1}{c|}{ Examples } \\
\hline $\begin{array}{l}\text { 'Package' or 'system' } \\
\text { that can work effec- } \\
\text { tively in multiple loca- } \\
\text { tions or situations. }\end{array}$ & $\begin{array}{l}\text { - reading systems for the blind first for English, then outside the US (1) } \\
\text { - publication of 'Youth at Risk: The Fight for Peace Methodologies Manual', } \\
\text { translated into six languages (6) } \\
\text { - creation of eight permanent environmental protection centres that offer } \\
\text { training classes on conservation, recycling, gardening, and ecotourism and } \\
\text { include greenhouses in which seedlings are cultivated to be replanted (6) }\end{array}$ \\
\hline $\begin{array}{l}\text { Easy to replicate our } \\
\text { programmes. }\end{array}$ & $\begin{array}{l}\text { individual-led change is a central element in the appeal of the Teach for } \\
\text { - Viva Rio's experience worked with transnational gun-control organisa- } \\
\text { tions (6) }\end{array}$ \\
\hline $\begin{array}{l}\text { Successful at control- } \\
\text { ling and coordinating } \\
\text { our programmes in } \\
\text { multiple locations. }\end{array}$ & $\begin{array}{l}\text { - launching or providing support for a series of community-based initiatives } \\
\text { in favelas (6) }\end{array}$ \\
\hline
\end{tabular}

Source: own elaboration.

The last part of the SCALERS model is Stimulating market forces. This element was less often recorded in the investigated cases. Only individual instances appear to be suitable for sub-criteria; in one case even none. Therefore, it is difficult to 'demonstrate that business can make money through supporting ISEs' activities'. In case \#1 it was possible to prove the business as for-profit is possible. In the next issue the approach applied in case \#3 is interesting as it emphasises not the product itself but the final result to which this product contributes. The last topic - ability to trust market forces to help resolve social problems - was not covered in papers describing cases (Table 9).

Table 9. Stimulating Market Forces in International Social Enterprises

\begin{tabular}{|l|l|}
\hline \multicolumn{1}{|c|}{ Stimulating market forces } & \multicolumn{1}{c|}{ Examples } \\
\hline $\begin{array}{l}\text { Able to demonstrate that businesses can make money } \\
\text { through supporting our initiatives. }\end{array}$ & $\begin{array}{l}\text { in the absence of supportive institu- } \\
\text { tional environments (1) }\end{array}$ \\
\hline $\begin{array}{l}\text { Able to demonstrate that consumers can save money } \\
\text { through patronising our products and services. }\end{array}$ & $\begin{array}{l}\text { the product is not the pump but rather } \\
\text { a successful, rural family enterprise (3) }\end{array}$ \\
\hline Able to trust market forces to help resolve social problems. & \multicolumn{1}{|c|}{-} \\
\hline
\end{tabular}

Source: own elaboration.

Based on the above descriptions of each organisation's capabilities, we can evaluate its significance. Table 10 shows the result of such analysis. Each sub-criterion was marked as: not very significant $(+)$, just significant $(++)$, and very significant $(+++)$. Where there was no note about a given topic, the question mark was used (?). 
We can notice that some of the criteria in a given group are more significant comparing to others. Trying to generalise this finding, the following inferences can be drawn. There is a differentiation in the sub-criteria in each main SCALERS's capability. The most consistent evaluation is in earnings generation and alliance building. The next almost coherent evaluation appears in communicating and stimulating market forces. The rest of the drivers have got diverse significance, such as in the case of staffing and replicating.

Table 10. Significance of Capabilities for Scaling International Social Enterprises

\begin{tabular}{|c|c|}
\hline Drivers & $\begin{array}{l}\text { Signifi- } \\
\text { cance }\end{array}$ \\
\hline \multicolumn{2}{|l|}{ Staffing } \\
\hline Effective meeting labour needs with people who have the necessary skills. & + \\
\hline An ample pool of capable volunteers available to help us meet our labour needs. & ++ \\
\hline $\begin{array}{l}\text { Individuals at management positions who have the skill to expand our organisation, pro- } \\
\text { gramme or principles. }\end{array}$ & +++ \\
\hline \multicolumn{2}{|l|}{ Communicating } \\
\hline Effective at communicating what we do to key constituencies and stakeholders. & +++ \\
\hline Successful at informing the individuals we seek to serve the value of our programme to them. & + \\
\hline Successful at informing donors and funders about the value of what we do. & +++ \\
\hline \multicolumn{2}{|l|}{ Alliance-building } \\
\hline Built partnerships with other organisations that have been win-win situations for us and them. & +++ \\
\hline Rarely trying to 'go it alone' when pursuing new initiatives. & ++ \\
\hline $\begin{array}{l}\text { Accomplished more through a joint action with other organisations than we could have } \\
\text { by flying solo. }\end{array}$ & +++ \\
\hline \multicolumn{2}{|l|}{ Lobbying } \\
\hline $\begin{array}{l}\text { Successful at getting government agencies and officials to provide financial support for } \\
\text { our efforts. }\end{array}$ & ++ \\
\hline $\begin{array}{l}\text { Successful at getting government agencies and officials to create laws, rules and regulations } \\
\text { that support our efforts. }\end{array}$ & ? \\
\hline Able to raise our cause to a higher place on the public agenda. & + \\
\hline \multicolumn{2}{|l|}{ Earnings generation } \\
\hline Generated a strong stream of revenues from products and services that we sell for a price. & +++ \\
\hline Cultivated donors and funders who have been major sources of revenue for us. & ++++ \\
\hline Found ways to finance our activities that keep us sustainable. & +++ \\
\hline \multicolumn{2}{|l|}{ Replicating } \\
\hline 'Package' or 'system' that can work effectively in multiple locations or situations. & +++ \\
\hline Easy to replicate our programmes. & ++ \\
\hline Successful at controlling and coordinating our programmes in multiple locations. & + \\
\hline \multicolumn{2}{|l|}{ Stimulating market forces } \\
\hline Able to demonstrate that businesses can make money through supporting our initiatives. & + \\
\hline $\begin{array}{l}\text { Able to demonstrate that consumers can save money through patronising our products } \\
\text { and services. }\end{array}$ & ++ \\
\hline Able to trust market forces to help resolve social problems. & $?$ \\
\hline
\end{tabular}
Source: own elaboration.

In order to receive a more general view on scaling ISE, the qualitative scale was rescaled using the scale 1-3-5. The final picture of averages for each of the main organisation's capabilities is depicted in Figure 2. From this illustration the most significant for scal- 
ing social enterprises internationally are: earnings generation, and alliance building. The second group of drives is constituted by staffing, communicating, and replicating. The less significant ones are lobbying and stimulating market forces.

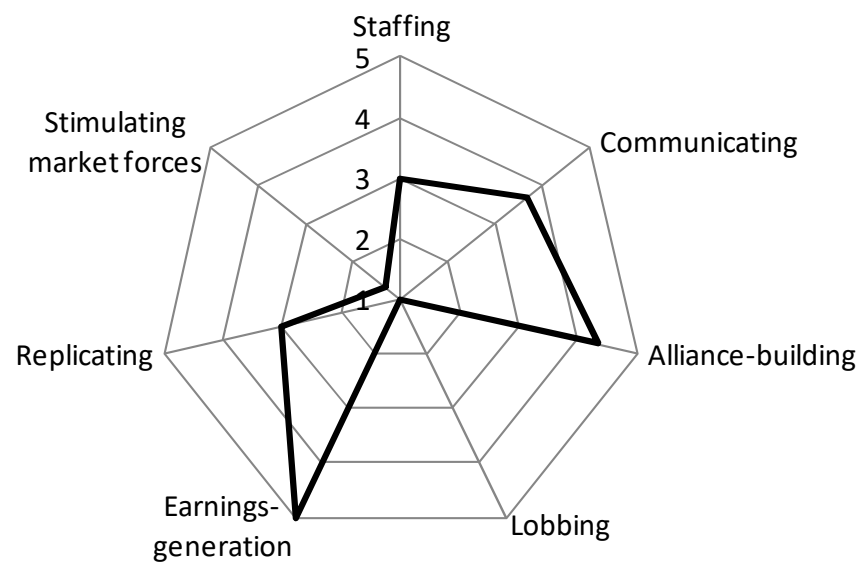

Figure 2. Significance of the SCALERS dimensions for an international social enterprise Source: own elaboration.

\section{DISCUSION AND CONCLUSIONS}

The presented results go along with the observation that prior to scaling social impact basic operational model must show its viability (Weber et al., 2012). In each case, the beginning of expanding operation into foreign countries was done after success in the country of origin.

Capabilities for ISEs scaling are differentiated in terms of their significance. It supports Bloom and Smith's comment that the appearance of capabilities is not set and 'in some situations, effective deployment of all the SCALERS may be needed for successful scaling' (Bloom \& Smith, 2010b, p. 13). In the case of ISEs this observation was proved with limitations described in the next part of the article.

We note differentiation which allows to conclude about the existence of a strong business model, neutral from market sources, well-resourced, recognised in the public sphere associated with scaling up. The last issue covers three dimensions (communicating, lobbying, and alliance buildings). It refers to embeddedness which is understood as the nature, depth and extent of an individual's ties into the environment' (Jack \& Anderson, 2002) and transposed to a level of the organisation means the degree of connection and interaction with local actors or stakeholders in the community' (Yang \& Wu, 2015, p. 39). We observe rather strong significance of alliance building and communicating together with weak lobbying. Albeit these terms are interrelated, these antecedents for scaling up were included in earlier studies on this phenomenon as part of political skills embracing: coalition formation, networking, advocacy, and lobbying (Frances \& Antadze, 2010).

Strong significance of earnings generating comes from all six cases included in the study. We can notice different approaches in this area due to the type of ISE (for-profit/not 
for-profit). The inclusion of this aspect in the description of each case corroborates its significance. It is one of the main features of social enterprise, which expresses its hybridity (Doherty, Haugh, \& Lyon, 2014).

Staffing was also found a significant factor. It is linked to the proposition about existing correlations between the managerial global vision elements and the company internationalisation scale (Kowalik, Danik, Král, \& Řezanková, 2017).

The less visible factor for ISE in scaling up is stimulating market forces. It would be false to state that this element was absent, but it was not fully reported. Provision of products by ISEs captured in the study relates to at least two of sub-criteria. Especially in case \#3 it is exemplified as for the company not selling goods is its main business logic, but to offer the development of the family enterprise through its product. This observation guides us to the limits of the study described in the last section of the article.

\section{LIMITATION AND FURTHER RESEARCH}

The research described in the article as every kind of scientific procedure has its own limitations. In the main one I include relying solely on secondary data taken from works picturing cases with different aims that one established in this article. Another limitation is due to conducting coding by myself, which could increase the risk of subjective evaluation of data which could lead to discrepancies and false conclusions. The next limitation stems from merging descriptions of different organisations which were treated as one case.

The limitations pointed out above can be overcome by the following directions of future research. First, it is recommended to collect primary data from ISEs which scaled up successfully using structured forms like the SCALERS model. The next suggestion is to analyse data by a team of researchers whose cooperation will strengthen internal validity thanks to triangulation used. Third, the scaling process should be reconstructed and attempt to investigate the influence of national settings on scaling up.

\section{REFERENCES}

Abbou, I., Gidron, B., Buber-Ben David, N., Greenberg, Y., Monnickendam-Givon, Y., \& Navon, A. (2017). Social enterprise in Israel: the swinging pendulum between collectivism and individualism. Social Enterprise Journal, 13(4, SI), 329-344. https://doi.org/10.1108/SEJ-09-2017-0043

Agrawal, S., \& Gugnani, R. (2014). Creating successful business model: lessons for social entrepreneurship. International Journal of Entrepreneurship \& Innovation Management, 18(5/6), 438 445. https://doi.org/10.1504/IJEIM.2014.064720

Bennett, E.A. (2016). Governance, legitimacy, and stakeholder balance: lessons from Fairtrade International. Social Enterprise Journal, 12(3), 322-346. https://doi.org/10.1108/SEJ-08-2016-0038

Bloom, P.N., \& Chatterji, A.K. (2009). Scaling Social Entrepreneurial Impact. California Management Review, 51(3), 114-133. https://doi.org/10.2307/41166496

Bloom, P.N., \& Skloot, E. (Eds.). (2010). Scaling Social Impact. New Thinking. New York: Palgrave Macmillan US. https://doi.org/10.1057/9780230113565

Bloom, P.N., \& Smith, B.R. (2010a). Identifying the Drivers of Social Entrepreneurial Impact: Theoretical Development and an Exploratory Empirical Test of SCALERS. Journal of Social Entrepreneurship, 1(1), 126-145. https://doi.org/10.1080/19420670903458042 
Bloom, P.N., \& Smith, B.R. (2010b). Indentifying the Drivers of Social Entrepreneurial Impact: An Exploratory Empirical Study. In Scaling Social Impact. New Thinking (pp. 11-27).

Bradach, J. (2010). Scaling Impact. Stanford Social Innovation Review, Summer.

Brouard, F., \& Elson, P.R. (2014). International Comparison of Social Enterprise Models (ICSEM). Canadian Journal of Nonprofit \& Social Economy Research / Revue Canadienne de Recherche Sur Les OSBL et l'économie Sociale, 5(1), 3-5.

Cannatelli, B. (2017). Exploring the Contingencies of Scaling Social Impact: A Replication and Extension of the SCALERS Model. Voluntas, 28(6), 2707-2733. https://doi.org/10.1007/s11266-016-9789-x

Davis, S. (2016). Relocating Development Communication: Social Entrepreneurship, International Networking, and South-South Cooperation in the Viva Rio NGO. International Journal of Communication, 10, 42-59.

Dees, G.J., Anderson, B.B., \& Wei-Skillern, J. (2004). Scaling social impact. Strategies for spreading social innovations. Stanford Social Innovation Review, Spring, 24-32.

Defourny, J., \& Nyssens, M. (2017). Mapping social enterprise models: some evidence from the "ICSEM" project. Social Enterprise Journal, 13(4, SI), 318-328. https://doi.org/10.1108/SEJ-09-2017-0049

Desa, G. (2012). Resource Mobilization in International Social Entrepreneurship: Bricolage as a Mechanism of Institutional Transformation. Entrepreneurship: Theory and Practice, 36(4), 727-751. https://doi.org/10.1111/j.1540-6520.2010.00430.x

Doherty, B., Haugh, H., \& Lyon, F. (2014). Social Enterprises as Hybrid Organizations: A Review and Research Agenda. International Journal of Management Reviews, 16(4), 417-436. https://doi.org/10.1111/ijmr.12028

Frances, W., \& Antadze, N. (2010). Making a Difference: Strategies for Scaling Social Innovation for Greater Impact. Innovation Journal, 15(2), 1-19.

Friedrich, D.S. (2014). Global microlending in education reform: Enseñá por Argentina and the Neoliberalization of the grassroots. Comparative Education Review, 58(2), 296-321. https://doi.org/10.1086/675412

Galera, G., \& Borzaga, C. (2009). Social enterprise. Social Enterprise Journal, 5(3), 210-228. https://doi.org/10.1108/17508610911004313

Galvin, M., \& Iannotti, L. (2015). Social Enterprise and Development: The KickStart Model. Voluntas: International Journal of Voluntary \& Nonprofit Organizations, 26(2), 421-441. https://doi.org/10.1007/s11266-013-9424-z

Jack, S.L., \& Anderson, A.R. (2002). The effects of embeddedness on the entrepreneurial process. Journal of Business Venturing, 17(5), 467-487. https://doi.org/10.1016/S0883-9026(01)00076-3

Jones, M.V., Coviello, N., \& Tang, Y.K. (2011). International Entrepreneurship research (1989-2009): A domain ontology and thematic analysis. Journal of Business Venturing, 26(6), 632-659. https://doi.org/10.1016/j.jbusvent.2011.04.001

Keupp, M.M., \& Gassmann, O. (2009). The Past and the Future of International Entrepreneurship: A Review and Suggestions for Developing the Field. Journal of Management, 35(3), 600-633. https://doi.org/10.1177/0149206308330558

Kowalik, I., Danik, L., Král, P., \& Řezanková, H. (2017). Antecedents of Accelerated Internationalisation of Polish and Czech Small and Medium-Sized Enterprises. Entrepreneurial Business and Economics Review, 5(3), 31-48. https://doi.org/10.15678/EBER.2017.050302

Oviatt, B.M., \& McDougall, P.P. (2005). Defining International Entrepreneurship and Modeling the Speed of Internationalization. Entrepreneurship Theory and Practice, 29(5), 537-554. https://doi.org/10.1111/j.1540-6520.2005.00097.x 
Petrů, N., \& Havlíček, K. (2017). Family entrepreneurship in the Czech Republic on the verge of first generation handover. Journal of International Studies, 10(4), 119-130. https://doi.org/10.14254/2071-8330.2017/10-4/9

Ratajczak-Mrozek, M. (2017). Interorganizational Network Embeddedness and Performance of Companies Active on Foreign Markets. Journal of Management and Business Administration. Central Europe, 25(4), 144-157.

Sarasvathy, S., Kumar, K., York, J.G., \& Bhagavatula, S. (2014). An Effectual Approach to International Entrepreneurship: Overlaps, Challenges, and Provocative Possibilities. Entrepreneurship: Theory and Practice, 38(1), 71-93. https://doi.org/10.1111/etap.12088

Tukamushaba, E., Orobia, L., \& George, B. (2011). Development of a conceptual model to understand international social entrepreneurship and its application in the Ugandan context. Journal of International Entrepreneurship, 9(4), 282-298.

Walske, J.M., \& Tyson, L.D. (2015). Built to Scale. A Comparative Case Analysis, Assessing How Social Enterprises Scale. The International Journal of Entrepreneurship and Innovation, 16(4), 269-281. https://doi.org/10.5367/ijei.2015.0197

Weber, C., Kröger, A., \& Lambrich, K. (2012). Scaling social enterprises - a theoretically grounded framework. Frontiers of Entrepreneurship Research, 32(19), 1-15.

Westley, F., Antadze, N., Riddell, D.J., Robinson, K., \& Geobey, S. (2014). Five Configurations for Scaling Up Social Innovation. The Journal of Applied Behavioral Science, 50(3), 234-260. https://doi.org/10.1177/0021886314532945

Yang, Y., \& Wu, S. (2015). An Exploratory Study to Understand the Internationalization Strategies of Social Enterprises. Journal of Social Entrepreneurship, 6(1), 31-41. https://doi.org/10.1080/19420676.2014.954255

Zahra, S.A., Newey, L.R., \& Li, Y. (2014). On the Frontiers: The Implications of Social Entrepreneurship for International Entrepreneurship. Entrepreneurship: Theory \& Practice, 38(1), 137-158. https://doi.org/10.1111/etap.12061

Zemaitaitiene, G., Tiskute, A., \& Tvaronaviciene, A. (2016). Enterprise Social Networking: Innovation Difficult to Adopt?. Economics \& Sociology, 9(2), 303-312 


\section{Author}

\section{Marek Ćwiklicki}

Marek Ćwiklicki is Professor of Business Studies and Public Management and Head of Chair for Management of Public Organisations at the Cracow University of Economics in Poland. He researches, writes, and lectures on organisation theory, business research methodology, and public management. He is a habilitated doctor of Economics within the discipline of management science, and holds PhD in Economics within the field of Management Science, both obtained in Cracow University of Economics in Poland.

Correspondence to: Marek Ćwiklicki, Cracow University of Economics, ul. Rakowicka 27, 31-510 Kraków, Poland, e-mail: marek.cwiklicki@uek.krakow.pl

ORCID (1) https://orcid.org/0000-0002-5298-0210

\section{Acknowledgements and Financial Disclosure}

The author would like to express his gratitude to Payal Jain for help in partial initial coding of articles for SLR section.

The publication is co-financed from the funds allocated by the Ministry of Science and Higher Education of the Republic of Poland to the Faculty of Economy and Public Administration of the Cracow University of Economics in the framework of grants for maintaining research potential.

\section{Copyright and License}

This article is published under the terms of the Creative Commons

Attribution - NoDerivs (CC BY-ND 4.0) License

http://creativecommons.org/licenses/by-nd/4.0/

Published by the Centre for Strategic and International Entrepreneurship - Krakow, Poland 